\title{
Reading Early New Testament Manuscripts
}

\author{
Scriptio continua, "Reading Aids", and Other Characteristic Features
}

\section{Introduction}

In his recent publication on the production and transmission of early Christian gospels, ${ }^{1}$ Scott D. Charlesworth works out criteria to distinguish early Christian manuscripts that have been produced/copied in controlled settings for "public" use from those that have been copied in uncontrolled settings for "private" usage. Charlesworth defines the category "public manuscripts" as "intentionally produced to be read aloud by lectors in Christian meetings." 2 As the main indicators for identifying public manuscripts, he points to "sense breaks," "punctuation," and "lectional signs,"

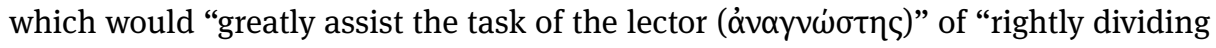
the continuous lines of letters in ancient texts (scriptio continua)" ${ }^{3}$ during ancient Christian worship. ${ }^{4}$ The term "sense break" refers to the paragraphos, a horizontal stroke found in the margins of ancient manuscripts. According to W. A. Johnson, on whom Charlesworth relies here, in papyri with literary texts, the paragraphos "was added primarily to assist with reading aloud-the typical way in which these literary texts would have been used." ${ }^{5}$ Under the term "lectional signs", Charlesworth includes markings on the level of letters and words, i. e. diacritics such as the trema, breathings and accents, as well as the apostrophe. In contrast, he suggests that the absence of these "reader's aids" in early manuscripts of New Testament texts indicates a private setting “where MSS were read by individuals or where 'private' readings for family or friends were conducted, there was more leisurely interaction with the text and the need for reader's aids was less pressing." 6

There is a fundamental methodological problem with Charlesworth's approach: the fragmentary state of most of the papyri he examines does not allow for any definite conclusion about the absence of (in his terminology) "reader's aids," especially diacritics. Even more problematic, in my view, is that he assumes the presence of an official early Christian worship with a communal reading or even a liturgy of the word. However, the question of the broader social context of early Christian worship is not

1 Cf. Charlesworth 2016. See also his preliminary studies: Charlesworth 2006, 2009, 2012.

2 Charlesworth 2016, 31.

3 Charlesworth 2016, 31.

4 It is common to link these so-called scribal features to (official) reading practices in early Christian worship. See, e. g., Aland 1989, 29f; Aland 2004, 109; Kruger 2013, 27, fn. 69; Hurtado 2006a, 171-185

5 Johnson 1994, 68.

6 Charlesworth 2016, 31.

Ә Open Access. (c) 2020 Jan Heilmann, published by De Gruyter. (c) BY-NC-ND This work is licensed under the Creative Commons Attribution-NonCommercial-NoDerivatives 4.0 License.

https://doi.org/10.1515/ 9783110639247-011 
the topic of this paper. In the following, I rather focus on the material dimension of the assumed interconnection between specific features in early New Testament manuscripts and early Christian worship.

This article is divided into two main parts. I will start by challenging certain conclusions drawn from the fact that New Testament manuscripts (as most of the ancient Greek papyri) were written in scriptio continua. Since this is particularly important for the topic of this article, it will be discussed in some detail. In a second step, I will discuss the function of other characteristic features of early New Testament manuscripts. I will primarily focus on diacritics (breathings, accents, diaereses) and the apostrophe. Short remarks on ektheseis, paragraphoi, and the so-called "nomina sacra" will follow.

\section{Reading Scriptio Continua}

The most striking characteristic not only of New Testament manuscripts, but almost all Greek manuscripts from antiquity (irrespective of the medium), is that they are written without spaces between words (scriptio continua). Scholars commonly suppose that texts written in scriptio continua are more difficult to decode than texts with spaces between words (scriptio discontinua). Therefore, scriptio continua would need to be decoded by auditory cognition through vocal realization of the text. The most elaborated defense of this view can be found in P. Saenger's book "Space between Words: The Origins of Silent Reading,"7 and it is a view commonly accepted in Classical Studies as well as New Testament Studies. ${ }^{8}$ However, the arguments of P. Saenger and others for the thesis that texts in scriptio continua were designed to be read aloud cannot carry the burden of proof for the proposed interrelationship. On the contrary, they presuppose precisely what must be proved.

The view that ancient scriptio continua had to be decoded phonologically is, on the one hand, based on outdated theories of word recognition; ${ }^{9}$ on the other hand, it is based on the postulated primacy of orality over literacy in ancient societies, specifically on the communis opinio that reading in antiquity was almost exclusively done aloud. This thesis was first formulated in the nineteenth century from a perspective of cultural pessimism ${ }^{10}$ and later expounded by J. Balogh in 1927: "Der Mensch des

7 Cf. Saenger 1997. But cf. already Balogh 1927, 228f; Schubart 1921, 80f; Sedgwick 1929, 93; Marrou 1956, 134; Mavrogenes 1980, 693.

8 See, e. g., Lefèvre 1990, 14f; Vogt-Spira 1991, 295, fn. 2; Raible 1991b; Parkes 1993, 10f; Frank 1994, 3642; Usener 1994, 96; Gamble 1995, 203f; Small 1997, 21, 53 and passim; Hezser 2001, 463f; Ehlers 2001, passim; Vegge 2006, 345; Hellholm 2006, 256f.; Hurtado 2006a, 179f; Hurtado 2009, 78; Charlesworth 2009, 148; Oestreich 2012, 67.123.174; Luz 2014, 164; Carr 2015, $12 f$.

9 For the limitations of the theory of the "Bouma-shape" and the Dual Route Cascaded Model (Coltheart), see Christmann 2015 with further references.

10 Cf. Nietzsche 1886, 207.382; Norden 1898, 6. 
Altertums las und schrieb in der Regel laut; das Gegenteil war zwar nicht unerhört, doch immer eine Ausnahme". ${ }^{11}$ It is still taken for granted today. Furthermore, it is presumed that ancient literature was generally produced for public delivery and performance. ${ }^{12}$ Well-argued counterproposals ${ }^{13}$ have not been accepted against this standard view, which has become a quasi-dogma. ${ }^{14}$

However, the standard view on reading aloud in antiquity is misleading for several reasons. I will provide only a few brief remarks. First of all, the simple distinction between reading aloud and reading silently is too narrow to describe the functional aspect of reading in antiquity, and it restricts the scope of sources under discussion. In my view, a more precise description of the reading practices reflected in the sources must distinguish between "use of the voice," on the one hand, and "volume/acoustic perceptibility" on the other. The sources clearly show that ancient readers could read with vocalization, subvocalization, or without vocalization. Reading with vocalization or subvocalization can further be described on a scale from loud to quiet. Non-vocalized reading is silent from the perspective of the outside observer, at least as concerns the voice of the reader. Moreover, the "inner reading voice" during reading without vocalization is often forgotten in discussions of reading in antiquity. The "inner reading voice" is not only reflected in ancient sources ${ }^{15}$ but is also applicable to reading in our times. ${ }^{16}$ It is therefore misleading to understand silent reading as a mere act of scanning a text and obtaining direct access to the information. Cognitive neuroscience shows that the phonological center of our brain is involved in every reading process. ${ }^{17}$

Thus, the common opinion that ancient readers generally read aloud and mostly in groups is based on a romantic view of antiquity originating in the nineteenth century. Of course, there are documented instances in which a person reads a text aloud for others. It is also documented that ancient readers did read texts for themselves with vocalization, but in that case it was done with a special purpose, e. g., aesthetic

11 Balogh 1927, 220.

12 Cf., e. g., Roberts 1970, 49; Havelock 1986, 47; Müller 1994, 18-30; Gamble 1995, passim; Jaffee 2001, 26; Kivy 2009, 16; Botha 2010, passim; Botha 2012, passim.

13 Cf., e. g., Knox 1968; Gavrilov 1997; Burnyeat 1997; Svenbro 1999, 2002, 2005; Burfeind 2002.

14 For this correct evaluation, see Krasser 1996, 170f.

15 Cf. Plut. mor. 961a; Aug. conf. 12,12.18; 13,44 etc.; Tractatus in Iohannis Euangelium 96,4; ep. 92,6; Leo M., Sermones 27,7,1. Furthermore, "hearing" a text does not necessarily mean that someone read a text aloud or that someone else read it to him. There are several instances (especially in private letter conversations) where ókoú $\omega$ simply refers to something that is "read". Cf., e. g., Hdt. 1.48; Isokr. Panath. 135-137; Ps.-Long. 7.1-3, Lib. epist. 414.1; 731.5 etc.; Eus. h. e. 1.13.5. And it is well documented that private letters were read mostly without vocalization. Moreover, the syntagma ״ $\lambda \varepsilon ́$ yovtos, as an equivalent for the Latin legere apud xy aliquid, is a common phrase for indicating a citation. See Schenkeveld 1992.

16 See Vilhauer 2016.

17 Cf. Rautenberg/Schneider 2015. 
pleasure, physical exercise or rhetorical training. ${ }^{18}$ However, the sources do not allow for statistical generalizations as one can find them as the basis of the common opinion outlined above. In unmarked cases, one cannot clearly decide if someone read with or without his voice.

Thus, generalizations about ancient reading practices cannot prove the proposed interrelationship of Greek scriptio continua on the one hand and vocalized and subvocalized reading on the other. In contrast, we do have evidence suggesting that reading scriptio continua did not lead on to any particular cognitive difficulties.

a) The results of cross-cultural experiments demonstrate that readers socialized in a writing system with scriptio continua can read this script without difficulties. To better understand the results of these recent studies, some brief remarks on the physiology of reading may be helpful. ${ }^{19}$

Eye movement during the reading process is structured in a sequence of so called "saccades" (fast forward movements, on average about 200-250 ms), "fixations" at a "preferred viewing location" (moments of stopping, on average about 20-40ms), and "regressions" (fast backward movements, on average 10-15\% of the speed of the "saccades"). Normally, the "preferred viewing location" (PVL) is just left of the center of a word, whereby on average $30 \%$ of the words are skipped. The term "parafoveal preview" describes the phenomenon during reading whereby the brain processes not only the currently fixed word, but also the letters/words right of the "fixation" (the so called perceptual span). "Parafoveal" refers to an area of the visual field that is up to $5^{\circ}$ around the center of visual perception, which is to be distinguished from peripheral perception. The information obtained in parafoveal perception controls eye movement-especially the length of the next "saccade," and thus the next point of "fixation." It then follows that for efficient control of eye movements, word boundaries must be recognized parafoveally. The question now is how exactly these word boundaries are identified.

Scholars commonly assume that readers identify word boundaries by means of spaces between words. This is concluded from empirical data demonstrating that average readers socialized in modern "western" scripts read English texts in scriptio continua slower and that the PVL shifts from the middle of the word to the beginning of the word. Hence, P. Saenger and other scholars conclude that it would have been difficult for people in antiquity to read scriptio continua and that they therefore needed to realize it phonologically by reading their texts aloud. However, this is methodologically problematic in that this research data is based exclusively on test subjects that have been socialized in modern "western" scripts and untrained in reading scriptio continua. Moreover, the results of J. Epelboim's studies in the 1990s suggest that one can train the

18 Cf. Krasser 1996, 190-206.

19 For the following, cf. Rayner 1998; Starr/Rayner 2001; Schotter/Angele/Rayner 2012; Ashby et al. 2012. 
eye to read scriptio continua and that spaces between words are not the primary factor controlling eye movement. ${ }^{20}$ Recent studies in fact indicate that the unconscious sensitivity to the frequency of certain letter combinations at the beginning and ending of words has a crucial function for word recognition during the reading process. ${ }^{21}$

For word recognition in ancient Greek scriptio continua, A. Vatri has convincingly argued that it is precisely this unconscious sensitivity to certain letter combinations that is central. His judgment is based on the results of recent cross-cultural comparative studies on reading, on the one hand, and his own analysis of the frequency of word beginnings and endings in ancient Greek on the other. Recent cross-cultural comparative studies show that the addition of spaces between words is redundant and can even disrupt the reading process. ${ }^{22}$ In the case of Thai script, which is an unspaced alpha-syllabic script, it could be shown "that the eye movements of Thai readers are exactly the same as those of English readers: the saccades land on the normal PVL, left of the middle of the words."23 This is of particular relevance for Greek scriptio continua, in that the Thai script as an unspaced alpha-syllabic script is more comparable to that of ancient Greek than the Liberian Vai syllabary, which P. Saenger refers to. ${ }^{24}$ It can be concluded from these data that "the readers' deep-rooted habits play a major role, and this must also have applied to the ancient readers of scriptura continua. [...] [T] here is no reason to assume that reading unspaced text is a particularly demanding cognitive task in itself, and Saenger's model must be rejected." 25 "No physiological constraints prevent the Greeks from reading silently."26

b) Furthermore, the ancient sources do not give any indication of such difficulties. ${ }^{27}$ The ancient sources cited to prove the supposed difficulty of reading scriptio continua cannot bear the burden of proof. These sources should rather be interpreted within the context of the process of learning to read and/or improving reading ability ${ }^{28}$ or

20 Cf. Epelboim/Booth/Steinman 1994; Epelboim et al. 1997; see also the controversy between Epelboim/Booth/Steinman 1996, on the one hand, and Rayner/Pollatsek 1996, on the other hand.

21 Cf. Pitchford/Ledgeway/Masterson 2008.

22 Cf. Vatri 2012, 638f., referring to Kajii/Nazir/Osaka 2001; Sainio et al. 2007, Bai et al. 2008. See also the results of the more recent study Bassetti/Lu 2016. For readers socialized in the German language, it has been proven that the addition of spaces within long composite nouns hinders the decoding of meaning. Cf. Inhoff/Radach/Heller 2000.

23 Vatri 2012, 639, referring to Winskel/Radach/Luksaneeyanawin 2009, $349 \mathrm{f}$.

24 Cf. Vatri 2012, 639, referring to Saenger 1997, 4.

25 Vatri 2012, 639.

26 Vatri 2012, 646f.

27 Against, e. g., Parkes 1993, 10f.; Oestreich 2012, 67; Mugridge 2016, 71, fn. 4.

28 Cf. Dion. Hal. comp. 25; Quint. inst. or. 1.1 .34 (context: rhetorical education); Lukian. adv. ind. 2; Petron. sat. 75.4 (cf. Krasser 1996, 173f). The examples of Greek papyri with spaces between words or syllables are school exercises (cf. Cribiore 1996, passim) and should be interpreted within the context of alphabetization. They do not demonstate the proposed cognitive challenges in reading scriptio continua. Against Cribiore 1996, 8f.47f.148f. 
within the context of discourses about illiteracy. ${ }^{29}$ This is not the place for a discussion of these sources; I do this in detail in my habilitation thesis. Moreover, some of the sources cited to prove the supposed difficulty of reading scriptio continua refer to Latin texts, ${ }^{30}$ which were not written in scriptio continua until the early imperial period. Finally, it must be emphasized that scribal errors due to scriptio continua ${ }^{31}$ do not prove that reading scriptio continua would have been particularly demanding.

c) Moreover, the fact that the Romans replaced their habit of writing scriptio discontinua with scriptio continua in the second century CE shows that scriptio continua is not a characteristic of deficient writing systems. ${ }^{32}$ R. P. Oliver drew attention to the late introduction of scriptio continua in Latin already in 1951. In the 1970s, E. O. Wingo studied Latin word separation in detail: „The practice of word-division was standard in Etruscan and it was probably from this source that it entered into Latin, where it is found in the very earliest inscriptions such as the lapis niger [CIL I $\left.{ }^{2} .1\right]$ and the fibula Praenestina ${ }^{33}$ [CIL I $\left.{ }^{2} .3\right]{ }^{34}$ The word-divider is regularly found on all good inscriptions, ${ }^{35}$ in papyri, ${ }^{36}$ on wax tablets, and even in graffiti from the earliest Republican times through the Golden Age and well into the Second Century." 37

29 Cf. Gell. 13.31.

30 Cf. Quint. inst. or. 1.1.34; Petron. sat. 75.4; Gell. 13.31.

31 Cf., e. g., Athen. deipn.1.11b referring to Hom. Il. 24.476; Serv. Aen. 2.798 referring to Aen. 2.289; Pomp. (Gram.) referring to Verg. Aen. 8.83 (GL 5, ed. Keil, p. 132). See also Brinkmann 1912.

32 In the ancient Greek world, too, one can detect a development from scriptio discontinua to scriptio continua. On word separations in Mycenaean and Archaic Greek inscriptions, see Wingo 1972, 14; Turner 1968, 57. Cretan inscriptions feature word separations as late as the 6th century. Cf. Gagarin/ Perlman 2016, 51.

33 On the question of authenticity cf. Simone 2011.

34 There are, however, also examples of early Latin inscriptions from the seventh to fifth century BCE written in scriptio continua. Cf. Wallace 2011, 22. For more information on early Latin inscriptions see Hartmann 2005. Yet this does not affect the problem dealt with here because word separation had been the standard since the Roman Republic. See also Wallace 2011, 23.

35 A well-known example is the inscription on the sarcophagus of Scipio Barbatus from the third century BCE (CIL I I .7).

36 Oliver refers to the following examples: P. Iand. 590 (CLA 8 1201; Cic. Verr. 22,3f.; 1st c. BCE/1st c. CE); P. Herc. 817 (CLA 3 385; Carmen de bello Actiaco; 1st c. BCE/1st c. CE); P. Oxy. 130 (CLA 2 207; fr. de bellis Macedonicis; 1st/2nd c.). Cf. especially the list of papyri and inscriptions in Wingo 1972, 15: 134-163. This list could be extended with numerous other examples. Cf., e. g., BGU II 611 (oration of Claudius; 1st c. CE). The fragments of the elegies of Gallus can also be added (1st c. BCE); they were only published in 1979 and show word separations with middle dots. Cf. Anderson/Parsons/Nisbet 1979 for this. Cf., e. g., also the following documentary papyri/ostraca with word separations: SB 16 12609 [!] (debt document; 27 CE); ChLA 10424 (private letter of recommendation; 1st c. CE); P. Oxy. 443208 (private letter; 1st c. BCE/1st c. CE); P. Berol. 7428 (list of veterans, 140 CE) or the numerous private letters from Didymoi, published by A. Bülow-Jacobsen in 2012, dating to the second half of the 1st c. CE: e. g. O. Did. 326; O. Did. 334; O. Did. 362; O. Did. 429.

37 Wingo 1972, 15. The transition from writing with frequent word separations to scriptio continua is documented impressively by the heterogeneous evidence of the Vindolanda tablets (around the turn 
Particularly noteworthy is papyrus PSI 7743 from the first or second century, which features Greek text in Latin transliteration with word separations. There is also a Greek inscription with word separations from Kom Ombi, Egypt (SB 58905 [88 CE]), where the application of Latin conventions seems probable, since the (dedicatory) inscription was funded by a Roman woman.

The differences between the conventions of the writing systems prior to the second century are also reflected in literary texts. Suetonius (Aug. 87.3), for example, finds it peculiar that Augustus did not separate individual words in his hand-written scripts (non dividit verba). ${ }^{38}$ Reflecting on what makes for a thoughtful philosophical speech (neither too slow nor too fast, cf. also Sen. ep.40.8.13f.), Seneca (ep. 40.10f.) compares Greek and Roman systems of writing: he associates Greek not with the difficulties of deciphering scriptio continua, but with speed. As for the word separation of Latin script, it is thought to reflect the opposite of licentia; that is, it is restrained in a way that not only reflects the thoughtfulness of the speech, but also the Latin language more generally.

In summary, there is no need to assume that reading unspaced scripts was any more cognitively challenging for ancient readers than reading spaced scripts is for us. ${ }^{39} \mathrm{We}$ should be careful not to project our difficulties with reading scriptio continua onto ancient readers.

\section{Characteristics of Early New Testament Manuscripts}

After deconstructing the commonly proposed interconnection between writing texts in scriptio continua and the alleged practice of only reading aloud in antiquity, I would now like to discuss the characteristics of early New Testament manuscripts (papyri and majuscules dated to the 2nd/3rd century). Here, the main focus will be on the function of diacritics (breathings, accents, trema/diaereses) as well as the apostrophe. As I already pointed out in the introduction, scholars mainly interpret diacritics,

from 1st/2nd century). Also Adams 1995, 95f. Whereas, for instance, in T. Vindol. II 297; 315; 323; 345 almost all words are separated from each other with a middle dot, in many other tablets the words are separated with spaces [!] (e. g. T. Vindol. II 296; 299; 301; 316; 343); only a few (e. g. T. Vindol. II 292) are in scriptio continua, while featuring analogous phenomena concerning the separation of abbreviations via spaces and middle dots (cf., e. g., T. Vindol. 291, 1. 1), which can also be found in papyri from Dura Europos (see below). On the issue of this transition, cf. further Müller 1964.

38 Cf. Krasser 1996, 175, fn. 13. It is also interesting that Augustus used these unspaced notes as an aid for speeches and even for conversations with his wife Livia (cf. Suet. Aug. 8.2). This means that in these situations he could visually comprehend the notes without any difficulty.

39 Already hinted at by Turner 1968, 57: "Regular reading of such continuous texts may make the reader quick at dividing words.“ 
punctuation, dicola, paragraphoi, etc., as aids for reading aloud or for performative readings. In the following, I will examine the manuscript evidence and show that this interpretation cannot be sustained.

1) As in other manuscripts of the Hellenistic and early Roman period, breathings are rare in early New Testament manuscripts and, if they do occur, it is usually a rough breathing $(\mathrm{H})$. However, most of the rough breathings found in the manuscripts function to indicate a semantic ambiguity in case of monosyllabic words (see Tab.1). They seem never to be found simply as phonetic markers.

It follows from this that the question of proper phonological realization had not been of interest for those who marked these ambiguous monosyllabic words. ${ }^{40}$ Parallels can also be found in non-Christian papyri-even in those clearly not intended to function as scripts for performative readings. ${ }^{41}$

2) Accents are even rarer in early New Testament manuscripts. However, if they can be found, they also appear to disambiguate meaning. In $\mathfrak{P} 1$ (P. Oxy. 11) vº.14 (Matt 1:18), the acute accent on n' distinguishes the particle from the article or from the ending or beginning letter of the surrounding words. In $\mathfrak{P} 46$ (P. Beatty 2) f. $26 \mathrm{v}^{0} .7$ (Hebr 6:16), the acute accent on $\pi \varepsilon \dot{\rho} \alpha \varsigma$ perhaps distinguishes the noun from the dative plural femi-

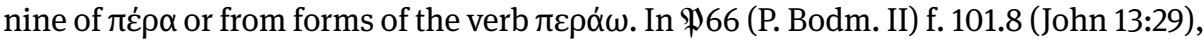

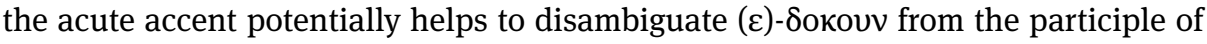

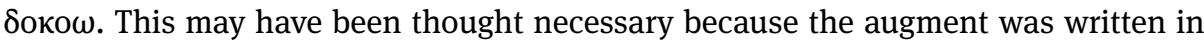
the previous line.

B. Laum concluded already in his 1928 study "Das alexandrinische Akzentuationssystem unter Zugrundelegung der theoretischen Lehren der Grammatiker und mit Heranziehung der praktischen Verwendung in den Papyri”:

Die Lesezeichen dienen dazu, bei Wörtern bzw. Buchstaben- und Wortverbindungen, die verschieden gedeutet werden können, dem Leser die richtige Auffassung klar zu machen. [...] Vor allem werden jene Wörter, die in der Buchstabenzusammensetzung gleich sind, aber je nach der Bedeutung verschieden betont werden können, mit dem zukommenden Akzent versehen. [...] Alle Zeichen (Akzente, Spiritus, Quantitäten und Diastolai) dienen also dem Zwecke, an mehrdeutigen Stellen dem Leser die richtige Auffassung kenntlich zu machen.“42

40 It is not certain whether marking monosyllabic words is a scribal habit or whether it goes back to the beginning of the textual transmission.

41 Cf., e. g., P. Oxy. 151809 (I/II; Plat. Phaid. 102e with extended scholia in the margins): col. 2.6f. The diacritical signs might even be from the same hand as the commentary (cf. CPF I.1 ${ }^{\star \star \star}$. 223); P. Berol. inv. 9782 (II; commentary manuscript): e. g. Pl. C ${ }^{\circ}$ col. 1.1; Pl. O ${ }^{\circ}$ col. 3.35; 38. Cf. also P. Berol. inv. 21245, fr. a $\mathrm{r}^{\mathrm{0}}$ (4th c.; fragments from Isocrates orations), bilingual lat.-gr.; spiritus lenis and acute

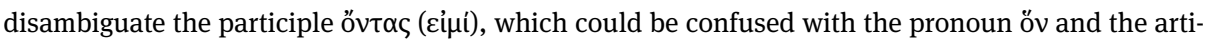
cle tós especially at the end of the line; and the spiritus on the monosyllabic words óv, ó and $\dot{\omega} \varsigma$ in P. Cairo. Masp. 367295 (6th c.).

42 Laum 1928, 451 f. 
Tab. 1: Examples for rough breathings in early NT Papyri.

\begin{tabular}{|c|c|c|}
\hline $\begin{array}{l}\text { Gregory-Aland }{ }^{43} \\
\text { standard abbreviation }\end{array}$ & reference & function \\
\hline $\begin{array}{l}\text { P13 (III/IV) } \\
\text { P. } 0 x y .4657\end{array}$ & f. $47 v^{0} .21 ; 27(\text { Hebr } 3: 6,8)^{44}$ & òv: relative pronoun vs. adverb \\
\hline $\begin{array}{l}\text { P15 ([III]/IV) } \\
\text { P. Oxy. } 71008\end{array}$ & $\begin{array}{l}r^{0} .5(1 \text { Cor } 7: 20)^{45} \\
v^{0} .13(1 \text { Cor } 7: 24)\end{array}$ & $\begin{array}{l}\dot{\eta}: \text { article vs. particle (disjunctive/ } \\
\text { comparative or adverb) } \\
\dot{\omega} \text { : disambiguation of the relative } \\
\text { pronoun }\end{array}$ \\
\hline $\begin{array}{l}\text { P4 } 45 \text { (III) } \\
\text { P. Beatty } 1\end{array}$ & $\begin{array}{l}\left.\text { f. } 10 v^{0} .5 \text { (Luke } 9: 48\right)^{46} \text { f. } 16 r^{0} .15 \\
\text { (John 10:16) }\end{array}$ & 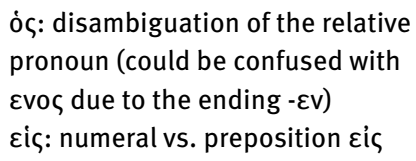 \\
\hline $\begin{array}{l}\text { P } 46^{47}(200-225) \\
\text { P. Beatty } 2\end{array}$ & $\begin{array}{l}\text { f. } 16 r^{0} .17 \text { (Rom 12:5) passim }{ }^{48} \\
\text { f. } 50 r^{0} .18(1 \text { Cor } 10: 17)\end{array}$ & 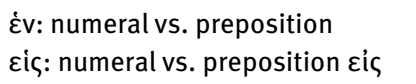 \\
\hline $\begin{array}{l}\text { P6649 (III) } \\
\text { P. Bodm. II }\end{array}$ & f. 101.10 (John 13:29) & $\begin{array}{l}\dot{\omega} \text { v: relative pronoun vs. present } \\
\text { participle }\left(\varepsilon i \mu{ }^{i}\right)\end{array}$ \\
\hline $\begin{array}{l}\text { P77 (III) } \\
\text { P. 0xy. } 644405\end{array}$ & f. $v^{0} .2$ (Matt 23:35) & 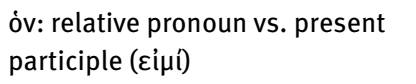 \\
\hline $\begin{array}{l}\text { P104 (II) } \\
\text { P. Oxy. } 644404\end{array}$ & $r^{0} .5$ f. (Matt 21:35)50 & $\begin{array}{l}\text { òv: relative pronoun vs. present } \\
\text { participle }(\varepsilon i \mu i)\end{array}$ \\
\hline $\begin{array}{l}\text { P113 (III) } \\
\text { P. Oxy. } 664497\end{array}$ & $v^{0} .5(\operatorname{Rom} 2: 29)$ & òu: relative pronoun vs. adverb \\
\hline
\end{tabular}

Laum evaluated Homer scholia and numerous papyri in which breathings and accents function to disambiguate meaning. ${ }^{51}$ Yet, as G. Nagy states rightly, "Laum's work has not received the attention it deserves. References by later scholars tend to focus on details that need to be corrected." 52

43 For the dating of the New Testament papyri, cf. Orsini/Clarysse 2012.

44 E. g. no rough breathing on $\alpha y ı$, f. $47 \mathrm{v}^{0} .11$ (Hebr 3:1).

45 E. g. no rough breathing on the relative pronoun, $v^{0} .9$.

46 E. g. no rough breathing on the relative pronoun os following kal, f. $10 v^{0} .6$.

47 The spiritus asper on the conjunction $\eta$ in $\$ 49$ (III/IV; P. Yale 2 86, $\mathrm{v}^{0} .8$; Eph 5:3) must be an error.

Cf. Biondi 1983, 26.

48 For this, cf. Ebojo 2013, 134, who mentions finding several dozen instances of the phenomenon in P46. Unfortunately, he does not list them individually.

49 In the first line of f. 102 there may be a spiritus lenis that disambiguates the preposition.

50 E. g. no rough breathing on the relative pronoun ol, $\mathrm{r}^{\mathrm{0}} .4$.

51 Cf. Laum 1928, 327-452.

52 Nagy 2000, 15. 
3) More often-even regularly-one finds the trema/diaeresis in early Christian manuscripts. ${ }^{53}$ Following the practice found in other manuscripts of the Hellenistic and early Roman period, one could distinguish between the "organic" use of the trema, "to separate those vowels in a cluster that do not belong together" [...] [JH: between or inside words], and the "inorganic" use of the trema "very often simply to mark an initial vowel" or "to emphasize a final vowel." 54 Inorganic uses of the trema are generally found only on iota and upsilon, ${ }^{55}$ as may be seen in the following examples.

Particularly instructive is, for instance, the use of the trema in John 1:29 in $\mathfrak{P} 66$ (P. Bodm. II) and $\mathfrak{P 7 5}$ (P. Bodmer 14-15), both 3rd c. CE. In P66f. 3, line 21, there is a trema on the initial iota of $t \delta \varepsilon$, even though the previous middle dot already indicates the separation of syllables/words $(\lambda \varepsilon-y \varepsilon ı \cdot i \delta \varepsilon)$. In contrast, $\mathfrak{P} 75$ has no middle dot in the same place, so the trema actually functions to indicate a diaeresis. One can find the same phenomenon, e. g., in John 1:36 (f. 4, line $18^{56}$ ) and elsewhere. This redundancy may have arisen because the writer of $\mathfrak{P} 66$ wrote the trema for conventional reasons or adopted it from his Vorlage. It is questionable whether the scribe of $\mathfrak{p 6 6}$ would have conceived the trema as a reading aid at all. Moreover, in P. Oxy. 3405, col. 2.19f (2nd/3rd c. CE; Iren. adv. haer.), we find a trema within a quotation from Matt 3:16f, on the first letter of a word beginning a new line. Incidentally, the quotation is marked by diple (>) in the margin, which is intended as a visual aid. ${ }^{57}$ Moreover, we see the trema in manuscripts containing commentaries, which were presumably not intended for performative readings. ${ }^{58}$

From this evidence, it seems doubtful that the trema should be categorized as a "lectional sign that guides pronunciation" 59 or that the trema should be brought into the context of performative or communal readings. Such a notion is also contradicted also by statistical findings. ${ }^{60}$

53 Cf. Mugridge 2016, 83f for the statistical findings.

54 E. g. Turner 1987, 12 f.

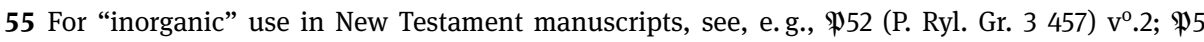

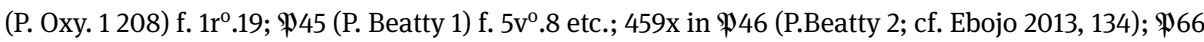

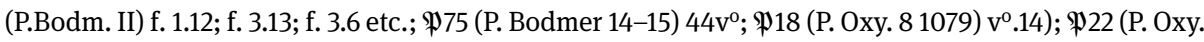
$101228) \mathrm{v}^{0} .12$.

56 In $\mathfrak{P} 75,45 r^{\circ} .7$ there might be an upper dot. This is, however, not clear from the digitized version. Only autopsy would bring further clarity.

57 Diog. Laert. 3.1.65f counts diple among the signs ( $\sigma \eta \mu \varepsilon \tilde{\alpha})$ in "useful” editions of Plato’s writings, and-as Antigonos of Karystos reports-owners of such editions gave other people access to them

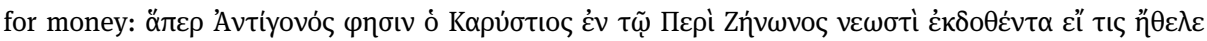

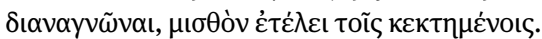

58 See, e. g., P. Berol. inv. 9782, Pl. C r ${ }^{0}$ col. 1.23; 25; col. 2.44 f; col. 3.5; Pl. E r ${ }^{\circ}$ col. 1.17; Pl. O ro col. 3 36, passim.

59 Nässelqvist 2016, 25. Also against Junack 1981, 283.

60 In A. Mugridge's category F (liturgical and hymnic texts) only $12.1 \%$ of the manuscripts feature tremata, while they can be found in $31.6 \%$ of New Testament papyri, in $41.7 \%$ of the papyri with Biblical apocrypha, and in $40 \%$ of the papyri with Patristic texts. Cf. Mugridge 2016, 86. 
4) The use of the apostrophe in early New Testament papyri is also illuminating. Similar to other manuscripts from the Hellenistic and the early imperial period, the apostrophe functions to indicate elision. Taking into account the fact that parafoveal word recognition in scriptio continua is guided primarily by letter combinations at the beginning and especially the end of words, as we saw above, the function of the apostrophe in the reading process becomes clear. If a letter is omitted for phonetic reasons, the apostrophe ensures regular word recognition. The process of parafoveal word recognition may also shed light on the common practice in early New Testament manuscripts of marking the end of indeclinable Semitic names with an apostrophe, something which scholars commonly recognize without any further explanation. ${ }^{61}$ Because of their unusual endings, these names are marked with an apostrophe so that the reader can identify them parafoveally. The practice of marking foreign words with an apostrophe is also widespread among documentary papyri. ${ }^{62}$ Therefore, the apostrophe is neither an aid for reading texts aloud nor a sign used for "clarity of pronunciation in the public reading." ${ }^{63}$ Instead, it is intended as an aid for word recognition, which can support the parafoveal perception of texts when reading aloud, but particularly functions in different modes of non-vocalized individual reading.

In conclusion, the occurrence of breathings and accents as well as the trema and apostrophe in early New Testament manuscripts does not permit one to infer their primary context of use. It is also not possible to conclude that they functioned "to enable a wider spectrum of people to read them, including readers of sub-elite social levels." ${ }^{\prime 4}$ One should note that these features can also be found in inscriptions ${ }^{65}$ and non-Christian papyri which were clearly used for study purposes-in grammatical textbooks, ${ }^{66}$ in manuscripts with commentaries ${ }^{67}$ or with annotations (in the margin

61 See, e. g., Turner 1987, 8.11. Ebojo 2013, 133 states: "the function of which is not immediately ascertainable."

62 Cf. Ast 2017, 151.

63 Metzger 1962, 201; Charlesworth 2009, 160.

64 Hurtado 2014, 337 referring to Hurtado 2011, 2012.

65 For the trema, see, e.g., IG II ${ }^{2} 2291 \mathrm{~b} .3$ (2nd c. CE; the trema on iva prevents its first two letters from becoming confused with the ending - $\alpha \sigma \mathrm{v}$ in the context); IG II ${ }^{2} 2089.42$ (2nd c. CE; on the first iota of a name); IG II 4514.25 (2nd c. CE). Cf. Threatte 1980, 94-97. For the rough breathing, see, e. g., IG II² 3662.9 (2nd c. CE; image at https://digital.library.cornell.edu/catalog/ss:456492 (last accessed 04.03.2019): disambiguating the relative pronoun $\mathrm{O} \Sigma$, which could be mistaken for the ending of ӨҮГАТНР. Cf. also IG II ${ }^{2} 12664.7$ (1st c. CE); IG II 2270.6 (2nd c. CE?); IG II 3714.12 (3rd c. CE); IG II² 3811.10 (before 250 CE). For this, cf. Threatte 1980,97f; Larfeld 1907, 428 also points out IG XIV 645, a very old inscription from the end of the 4th c. BCE, in which the spiritus asper is used. For the apostrophe, see, e. g., IG II 13131.5 (1st c. CE); IG II² 12664.8 (1st c. CE); IG II² 11040.2 (2nd c. CE); IG II 3714.12 (around 200 CE); IG II² 12617,2f.7. Cf. Threatte 1980, $97 \mathrm{f}$.

66 Cf. the accents in P. Berol. inv. 9917 (around 300).

67 Cf., e.g., the tremata in P. Berol. 9780 r $^{0}$ (2nd/3rd c.; commentary by Didymos on Demosthenes orations). 
or interlinear). ${ }^{68}$ Even more impressive are diacritics in lists or other documentary papyri, which makes it very unlikely that diacritics were used for performative readings. Thus, marking ambiguous monosyllabic words, using the apostrophe and the trema as well as sense-unit divisions marked by ektheseis and paragraphoi (see below) do not seem to have been the habit of single scribes, but were rather a general scribal or even cultural convention. ${ }^{69}$ Hence, the idea of a "pure" scriptio continua-text in the autograph or initial text (often presupposed in New Testament exegesis and textual criticism) is misleading. ${ }^{70}$ However, the exact reconstruction of those markings in the autographs as well as in the initial text seems to be difficult.

To get a more complete picture of the features of New Testament manuscripts, I would like to add a few remarks on ektheseis and paragraphoi, which occasionally occur in early New Testament manuscripts and function as sense breaks. ${ }^{71}$ As already mentioned in the introduction, Charlesworth, following W. A. Johnson, suggests that the paragraphos assists in reading literary texts aloud (in communal readings). However, there is evidence against this thesis: Paragraphoi are also found in commentary texts ${ }^{72}$ and medical treatises ${ }^{73}$ as well as in documentary papyri and ostraca. ${ }^{74}$ Thus, in ancient manuscripts the paragraphos as well as ektheseis function to structure marks in a broader sense and not necessarily as aids for reading a text aloud.

68 Cf., e. g., P. Berol. inv. 13236 (2nd/3rd c.) -a fragment of a codex containing Thuc. hist. (2.65.6-8; 65.12; 67.2; 68.1-5; 79.5-6; 80.3-6; 81.1-3; 81.8-82), whose text includes acute accent, circumflex accent, grave accent, breathings and scholia from the same hand. Cf. on the scholia McNamee 2007, 444f. In P. Oxy. 523680 (2nd c.; Plat. Tht.) a commentary from a second hand that features an apostrophe can be found in the margin. Cf. for this McNamee 2007, 351. Further, the evidence in P. Oxy. 151808 (2nd c.) is instructive: the fragment from Plato's Republic contains diacritical signs (e. g. a trema and a spiritus asper) and numerous quickly written margin notes (shorthand and abbreviations). McNamee 2007, 20f.352, suggests that the margin notes could have been written under time pressure during a lecture or speech. In this case, it would clearly not be a manuscript meant for public reading. In P. Berol. inv. 21355 (2nd c.) there is an apostrophe that indicates an elision in a scholion. In P. Berol. 5865 ( $3 \mathrm{rd} / 4$ th c.), the remains of a codex with Aratus scholia, there are tremata, apostrophes, spiritus asper as well as different reference signs (e. g. a small cross and a diple). Cf. for this with references to other papyri Maehler 1980. Cf. further P. Oxy. 473326 (2nd c.; Plat. rep.; cf. McNamee 2007, 352); P. Oxy. 182176 (2nd c.; commentary on Hipponax with scholia; cf. McNamee 2007, 265f.) and the evidence in fn. 41. Cf. also the autographical concept of a prose text from the 2nd c. BCE (P. Berol. 11632), which also includes accents.

69 Cf. Adams 2015, 65: "[T]he use of sense-unit divisions needs to be viewed as a scribal convention and part of a culturally conditioned writing practice."

70 Against Dronsch 2010, $244 \mathrm{f}$.

71 See, e. g., Porter 2005. However, many of the early New Testament papyri are too fragmentary to draw conclusions about sense-unit divisions.

72 Cf., e. g., P. Berol. inv. 11749 (second fragment on the didactics of surgery); commentary on Plat. pol.); P. Berol. $9780 \mathrm{r}^{\mathrm{O}}$ (see above); P. Heid. G inv. 28 (3rd c.; commentary on Plat. Phaid.).

73 Cf., e. g., P. Berol. inv. 9764 (1st c.); P.Ant. 128 (3rd-6th c.; Hippokr. Aph. 1.1-3; prog. 24f).

74 Cf., e. g., P. Berol. inv. 5855 r r 20/21, 23/24, $25 / 26$ (= BGU 10 1971; receipt, 2nd c. BCE); P. Berol. inv. $9765 \mathrm{r}^{\circ}$ Kol. 2, 1. 2/3 (medical recipes, 2nd c. CE); P. Köln inv. 21107, 1. 20/21 (= P. Köln XI 448; instructions 
Additionally, the nomina sacra, which can be found in nearly all early New Testament manuscripts, were intended primarily for visual perception. Nomina sacra are a system of contractions for important names in the New Testament writings-usually the first and last letter of a name (sometimes three letters) are marked with a supralinear horizontal stroke. It is an unusual form of abbreviation that neither derives from the use of the tetragrammaton nor functions to save space or time in writing. Moreover, the form of nomina sacra does not correspond to the usual abbreviation conventions in antiquity, which were characterized primarily by suspensions. In comparison to the diversity of situational abbreviation practices in antiquity there is also a considerably higher degree of standardization. ${ }^{75}$ There is evidence that a common set of

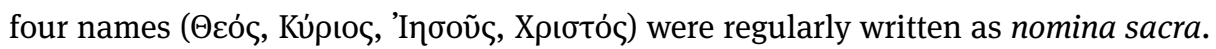
This suggests that the system was invented quite early, even though its exact origin is controversial. Among the symbolic signs in the New Testament manuscripts, the socalled "staurogram" $(\phi)$, which is also old,${ }^{76}$ is particularly relevant for the question of how the features of New Testament manuscripts relate to early Christian reading

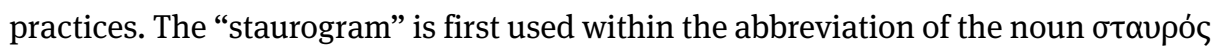

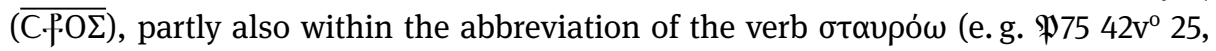
Luke 24:7 $\overline{C \cdot P \Omega \Theta H N A I}) .{ }^{77}$ It is clear that the "staurogram" is an iconographic sign for the crucifixion. ${ }^{78}$ Like the nomina sacra, the "staurogram" was invented for visual and not auditory perception. It is incomprehensible-especially in the light of my considerations in the first part of this article-that visual signs like the nomina sacra and the "staurogram" functioned as aids for reading New Testament texts aloud in worship, as C. M. Tuckett has proposed. ${ }^{79}$ In my view, these signs need to be interpreted within the broader context of other signs in ancient manuscripts that were intended for visual perception, such as acrostics, letter and alphabet plays, palindromes, the phenomenon of isopsephy, pattern poetry, ${ }^{80}$ and also graphical representations or small drawings. ${ }^{81}$

on distribution of grain); P. Berol. inv. 1548 passim (=BGU II 499; list of inhabitants, 2nd c. CE); P. Köln inv. $2331 \mathrm{r}^{\circ}$ (=P. Köln XI 437). Note also the multitude of ostraca: O. Berol. inv. 12331 Z.6/7 (= BGU VII 1519; notes on payments, 3rd/2nd c. BCE); O. Berol. inv. 513, 1. 4/5 (= O. Wilck. 2 701; receipt, 114 BCE); O. Berol. inv. 8616, 1. 5/6, 6/7 (accounts, 1st c. CE).

75 See the instructive summary provided by Trobisch 1996, 17-28, referring to corresponding studies of which the study by Paap 1959 in particular is still relevant.

$76 \mathfrak{P} 45, \mathfrak{P} 66$, and $\mathfrak{P} 75$, so not later than the first half of the 2nd c. CE.

77 Cf. K. Aland 1967; Dinkler-von Schubert 1995.

78 Cf. Hurtado 2000, 280-83; Hurtado 2006b, 219-221.225f., with source evidence showing that Christians understood the Greek letter "tau" as a symbol for the cross from very early on (Barn. 9.7-9; Iust. Mart. apol. 1.55; 1.60; Tert. adv. Marc. 3.22).

79 See Tuckett 2003, 455.

80 Cf. Luz 2010; Ast/Lougovaya 2015.

81 Cf. P. Berol 9875 (Timotheos of Milet, The Persians): This papyrus from the 4th c. BCE features a small drawing between cols. 4 and 5 (Tim. Pers. 214) that is interpreted as a coronis in the form of a bird and functions as a structuring element. For further reference to other papyri featuring ornamental design characteristics, cf. Fischer-Bossert 2005. 
Furthermore, no conclusions on the main use of the manuscripts can be drawn from their average line length, either. ${ }^{82}$

In my inspection of the manuscripts dated to the second and third centuries, I could only find a few manuscripts with secondary strokes which seem to indicate when a reader would want to pause while reading the text to an audience. That is, not all texts in these codices were marked with these strokes, but only those texts or passages prepared for a reading; ${ }^{83}$ and if they could be found in one of the texts of the codices, they occurred relatively regularly according to the content and syntactic aspects of the text. While the lack of strokes in manuscripts does not preclude the possibility that these texts functioned as scripts for performative readings, those who postulate the thesis that concrete manuscripts functioned as scripts for performative readings need to carry the burden of proof.

\section{Conclusions}

The so-called "reading aids" or "lectional signs" in early papyri of the New Testament neither function exclusively to facilitate performative or public readings nor indicate a "liturgical use" of those texts. ${ }^{84}$ Breathings, accents, and tremata primarily function to clarify semantic ambiguities, while the apostrophe marks the unusual endings of words. These diacritics all functioned to assist in reading without vocalization. Consequently, it is misleading to understand ancient papyrus scrolls mainly as scripts for performative readings ${ }^{85}$ or to compare texts in scriptio continua to sheet music. ${ }^{86}$

82 Against Paul H. Saenger 1982, 378; Johnson 2000, 609-612; Hurtado 2006a, 171-77. For my point of view, cf. Battezzato 2009, who proposes that narrow columns function as aids for fast and efficient reading/scanning. It is also significant that the average line length in papyri, which clearly functioned as performance scripts, tended to be significantly wider than the 15-25 letters which in Johnson's view were optimal for word recognition in performative contexts. See, e. g., the papyri with musical notations: P. Vindob. G. 2315; P. Leid. inv. 510; P. Mich inv. 2958; P. Berol. inv. 6870; P. Oxy. 151786.

83 Mark and Acts in 945 (P. Beatty 1), but not Luke and John; in $\mathfrak{P} 46$ (P. Beatty 2/P. Mich. inv. 6238) the strokes occur in passages of Romans, the last chapters of 1st Corinthians, and in Hebrews. Cf. Sanders $1935,17-19$; the strokes can also be found in $\mathfrak{P 3 7}$, which cannot be systematically evaluated due to its fragmentary state. According to H. A. Sanders, strokes also occur in $\mathfrak{P} 13$ (P. Oxy. 4 657), in $\mathfrak{P 1 7}$ (P. Oxy. 8 1078) and in the LXX papyrus 967 (Rahlfs; P. Beatty 7 9-10; P. Köln Theol. 3ff.). Cf. Sanders 1935, 18. 84 Cf. the judgment of D. Nässelqvist: "Many of the distinctive features-including the lectional signs-that are found in the studied manuscripts do not function as aids to lectors in a public reading context." Nässelqvist 2016, 53.

85 Against, e. g., Johnson 2004, passim; 2009, passim.

86 Against, e. g., Hendrickson 1929, 184. 


\section{Bibliography}

Adams, James N. (1995), “The Language of the Vindolanda Writing Tablets: An Interim Report”, in: Journal of Roman Studies 85, 86-134.

Adams, Sean A. (2015), "Mark, Manuscripts, and Paragraphs: Sense-Unit Divisions in Mark 14-16", in: Chris Keith and Dieter Roth (eds.), Mark, Manuscripts, and Monotheism: Essays in Honor of Larry W. Hurtado (Library of New Testament Studies 528), London, 61-78.

Aland, Barbara (1989), "Die Rezeption des Neutestamentlichen Textes in den Ersten Jahrhunderten", in: Jean-Marie Sevrin (ed.), The New Testament in Early Christianity: La Réception Des Écrits Néotestamentaires Dans Le Christianisme Primitif (Bibliotheca ephemeridum theologicarum Lovaniensium 86), Leuven, 1-38.

Aland, Barbara (2004), "The Significance of the Chester Beatty Papyri in Early Church History", in: Charles Horton (ed.), The Earliest Gospels: The Origins and Transmission of the Earliest Christian Gospels - the Contribution of the Chester Beatty Gospel Codex P45 (Journal for the Study of the New Testament: Supplement Series 258), London/New York, 108-121.

Aland, Kurt (1967), "Bemerkungen zum Alter und Entstehung des Christogramms anhand von Beobachtungen bei P66 und P75", in: Kurt Aland, Studien zur Überlieferung des Neuen Testaments und seines Textes (Arbeiten zur neutestamentlichen Textforschung 2), Berlin, 173-179.

Anderson, Robert D./Parsons, Peter J./ Nisbet, Robin G. Murdoch (1979), "Elegiacs by Gallus from Qașr Ibrîm”, in: Journal of Roman Studies 69, 125-155.

Ashby, Jane/Yang, Jinmian/Evans, Kris H. C./Rayner, Keith (2012), “Eye Movements and the Perceptual Span in Silent and Oral Reading", in: Attention, Perception \& Psychophysics 74 (4), 634-640.

Ast, Rodney (2017), "Signs of Learning in Greek Documents: The Case of spiritus asper", in: Gabriel Nocchi Macedo and Maria C. Scappaticcio (eds.), Signes dans les textes, textes sur les signes: Érudition, lecture et écriture dans le monde gréco-romain, Liège, 143-157.

Ast, Rodney/Lougovaya, Julia (2015), “The Art of the Isopsephism in the Greco-Roman World”, in: Andrea Jördens (ed.), Ägyptische Magie und ihre Umwelt, Wiesbaden, 82-98.

Bai, Xuejun/Yan, Guoli/Zang, Chuanli/Liversedge, Simon P./Rayner, Keith (2008), “Reading Spaced and Unspaced Chinese Text: Evidence from Eye Movements", in: Journal of Experimental Psychology: Human Perception and Performance 34 (5), 1277-1287.

Balogh, Josef (1927), “Voces Paginarum. Beiträge zur Geschichte des lauten Lesens und Schreibens", in: Philologus 82, 84-109.202-240.

Bassetti, Bene/Lu, Mehui (2016), "Effects of Interword Spacing on Native English Readers of Chinese as a Second Language", in: International Review of Applied Linguistics in Language Teaching 54 (1), 1-22.

Battezzato, Luigi (2009), “Techniques of Reading and Textual Layout in Ancient Greek Texts”, in: Cambridge Classical Journal 55, 1-23.

Biondi, Alessandro (1983), Gli accenti nei papiri greci biblici (Papyrologica Castroctaviana 9), Rom.

Botha, Pieter J. J. (2010), “'Publishing' a Gospel: Notes on Historical Constraints to Gospel Criticism”, in: Annette Weissenrieder and Robert B. Coote (eds.), The Interface of Orality and Writing:

Speaking, Seeing, Hearing, Writing in the Shaping of New Genres (Wissenschaftliche Untersuchungen zum Neuen Testament 260), Tübingen, 335-352.

Botha, Pieter J. J. (2012), Orality and Literacy in Early Christianity (Biblical Performance Criticism 5), Eugene, $\mathrm{OR}$.

Brinkmann, August (1912), "Scriptio continua und Anderes”, in: Rheinisches Museum für Philologie 67, 609-630.

Burfeind, Carsten (2002), “Wen hörte Philippus? Leises Lesen und lautes Vorlesen in der Antike”, in: Zeitschrift für die neutestamentliche Wissenschaft 93, 138-145.

Burnyeat, Myles F. (1997), “Postscript on Silent Reading”, in: Classical Quarterly 47 (1), 74-76. 
Carr, David M. (2015), Schrift und Erinnerungskultur: Die Entstehung der Bibel und der antiken Literatur im Rahmen der Schreiberausbildung, trans. by Martin Leuenberger et al. (Abhandlungen zur Theologie des Alten und Neuen Testaments 107), Zürich.

Charlesworth, Scott D. (2006), "Consensus Standardization in the Systematic Approach to Nomina Sacra in Second- and Third-Century Gospel Manuscripts", in: Aegyptus 86, 37-38.

Charlesworth, Scott D. (2009), "Public and Private-Second- and Third-Century Gospel Manuscripts", in: Craig A. Evans and Daniel Zacharias (eds.), Jewish and Christian Scripture as Artifact and Canon (Studies in Scripture in Early Judaism and Christianity 13), London, 148-175.

Charlesworth, Scott D. (2012), “Indicators of 'Catholicity' of Early Christian Manuscripts”, in: Charles E. Hill and Michael J. Kruger (eds.), The Early Text of the New Testament, Oxford, 37-48.

Charlesworth, Scott D. (2016), Early Christian Gospels: Their Production and Transmission (Papyrologica Florentina 45), Florenz.

Christmann, Ursula (2015), “Kognitionspsychologische Ansätze”, in: Ursula Rautenberg and Ute Schneider (eds.) Lesen: Ein Handbuch, Berlin, 21-45.

Cribiore, Raffaella (1996), Writing, Teachers, and Students in Graeco-Roman Egypt (American Studies in Papyrology 36), Atlanta, GA.

Dinkler-von Schubert, Erika (1995), “CTAYROC: Vom „Wort vom Kreuz” (1 Kor. 1,18) zum Kreuz-Symbol”, in: Christopher Moss (ed.), Byzantine East, Latin West: Arthistorical Studies in Honour of Kurt Weitzmann, Princeton, NJ, 29-39.

Dronsch, Kristina (2010), Bedeutung als Grundbegriff neutestamentlicher Wissenschaft: Texttheoretische und semiotische Entwürfe zur Kritik der Semantik dargelegt anhand einer Analyse zu akuein in Mk 4 (Neutestamentliche Entwürfe zur Theologie 15), Tübingen.

Ebojo, Edgar B. (2013), "When Nonsense Makes Sense: Scribal Habits in the Space-Intervals, SensePauses, and Other Visual Features in Formula 46", in: The Bible Translator 64 (2), 128-150.

Ehlers, Widu-Wolfgang (2001), "Auribus Escam oder der Intendierte Rezitator - produktions- und rezeptionsästhetische Aspekte der Mündlichkeit antiker Texte”, in: Lore Benz (ed.), ScriptOralia Romana: Die Römische Literatur zwischen Mündlichkeit und Schriftlichkeit, Tübingen, 11-42.

Epelboim, Julie/Booth, James R./Steinman, Robert M. (1994), “Reading Unspaced Text: Implications for Theories of Reading Eye Movements", in: Vision Research 34, 1735-1766.

Epelboim, Julie/Booth, James R./Steinman, Robert M. (1996), “Much Ado bout Nothing: The Place of Space in Text”, in: Vision Research 36 (3), 465-470.

Epelboim, Julie/Booth, James R./Ashkenazy, Rebecca/Taleghani, Arash/Steinman, Robert M. (1997), "Fillers and Spaces in Text: The Importance of Word Recognition During Reading", in: Vision Research 37 (20), 2899-2914.

Evans, Craig A./Zacharias, Daniel (eds.) (2009), Jewish and Christian Scripture as Artifact and Canon (Studies in Scripture in Early Judaism and Christianity 13), London.

Fischer-Bossert, Wolfgang (2005), “Die Koronis im Berliner Timotheospapyrus”, in: Archiv für Papyrusforschung und verwandte Gebiete 51 (2), 191-195.

Frank, Barbara (1994), Die Textgestalt als Zeichen: Lateinische Handschriftentradition und die Verschriftlichung der romanischen Sprachen (Script-Oralia 67), Tübingen.

Gagarin, Michael/Perlman, Paula (2016), The Laws of Ancient Crete: C.650-400 BCE, Oxford.

Gamble, Harry Y. (1995), Books and Readers in the Early Church: A History of Early Christian Texts, New Haven, MA.

Gavrilov, Aleksandr K. (1997), “Techniques of Reading in Classical Antiquity”, in: Classical Quarterly 47, 56-73.

Hartmann, Markus (2005), Die frühlateinischen Inschriften und ihre Datierung: Eine linguistisch-archäologisch-paläographische Untersuchung (Münchner Forschungen zur historischen Sprachwissenschaft 3), Bremen. 
Havelock, Eric A. (1986), The Muse Learns to Write: Reflections on Orality and Literacy from Antiquity to the Present, New Haven, MA.

Hellholm, David (2006), “Universalität und Partikularität: Die amplifikatorische Struktur von Römer 5,12-21”, in: Dieter Sänger and Jürgen Becker (eds.), Paulus und Johannes: Exegetische Studien zur paulinischen und johanneischen Theologie und Literatur (Wissenschaftliche Untersuchungen zum Neuen Testament 198), Tübingen, 217-270.

Hendrickson, George L. (1929), “Ancient Reading”, in: The Classical Journal 25, 182-196

Hezser, Catherine (2001), Jewish Literacy in Roman Palestine (Texts and Studies in Ancient Judaism 81), Tübingen.

Hurtado, Larry W. (2000), “The Earliest Evidence of an Emerging Christian Material and Visual Culture: the Codex, the Nomina Sacra, and the Staurogram", in: Michel Desjardins and Stephen G. Wilson (eds.), Text and Artifact in the Religions of Mediterranean Antiquity: Essays in Honour of Peter Richardson (Studies in Christianity and Judaism 9), Waterloo, Ont., 271-288.

Hurtado, Larry W. (2006a), The Earliest Christian Artifacts: Manuscripts and Christian Origins, Grand Rapids, MI.

Hurtado, Larry W. (2006b), "The Staurogram in Early Christian Manuscripts: the Earliest Visual Reference to the Crucified Jesus?,” in: Thomas J. Kraus and Tobias Nicklas (eds.), New Testament Manuscripts: Their Texts and Their World (Text and Editions for New Testament Study 2), Leiden, 207-226.

Hurtado, Larry W. (2009), “Early Christian Manuscripts as Artifacts”, in Craig A. Evans and Daniel Zacharias (eds.), Jewish and Christian Scripture as Artifact and Canon (Studies in Scripture in Early Judaism and Christianity 13), London, 66-81.

Hurtado, Larry W. (2011), “What Do the Earliest Christian Manuscripts Tell Us About Their Readers?," in: Craig A. Evans (ed.), The World of Jesus and the Early Church: Identity and Interpretation in Early Communities of Faith, Peabody, MA, 179-192.

Hurtado, Larry W. (2012), "Manuscripts and the Sociology of Early Christian Reading”, in: Charles E. Hill and Michael J. Kruger (eds.), The Early Text of the New Testament, Oxford, 49-62.

Hurtado, Larry W. (2014), “Oral Fixation and New Testament Studies? 'Orality', 'Performance' and Reading Texts in Early Christianity”, in: New Testament Studies 60 (3), 321-340.

Inhoff, Albrecht W./Radach, Ralph/Heller, Dieter (2000), “Complex Compounds in German: Interword Spaces Facilitate Segmentation but Hinder Assignment of Meaning", in: Journal of Memory and Language 42 (1), 23-50.

Jaffee, Martin S. (2001), Torah in the Mouth: Writing and Oral Tradition in Palestinian Judaism, $200 B C E-400$ CE, New York.

Johnson, William A. (1994), "The Function of the Paragraphus in Greek Literary Prose Texts", in: Zeitschrift für Papyrologie und Epigraphik 100, 65-68.

Johnson, William A. (2000), "Toward a Sociology of Reading in Classical Antiquity", in: American Journal of Philology 121 (4), 593-627.

Johnson, William A. (2004), Bookrolls and Scribes in Oxyrhynchus (Studies in Book and Print Culture), Toronto/Buffalo, NY.

Johnson, William A. (2009), “Constructing Elite Reading Communities in the High Empire”, in: William A. Johnson and Holt N. Parker (eds.), Ancient Literacies: The Culture of Reading in Greece and Rome, Oxford, 320-330.

Junack, Klaus (1981), “Abschreibpraktiken und Schreibergewohnheiten in ihrer Auswirkung auf die Textüberlieferung", in: Eldon J. Epp and Gordon D. Fee (eds.), New Testament Textual Criticism: Its Significance for Exegesis. Essays in Honour of Bruce M. Metzger, Oxford, 277-295.

Kajii, Natsumi/Nazir, Tatjana A./Osaka, Naoyuki (2001), “Eye Movement Control in Reading Unspaced Text: The Case of the Japanese Script”, in: Vision Research 41 (19), 2503-2510. 
Kivy, Peter (2009), The Performance of Reading: An Essay in the Philosophy of Literature (New Directions in Aesthetics 3). Malden, MA.

Knox, Bernard M. W. (1968), "Silent Reading in Antiquity", in: Greek, Roman and Byzantine Studies 9, 421-435.

Krasser, Helmut (1996), “Sine fine lecturias": Zu Leseszenen und literarischen Wahrnehmungsgewohnheiten zwischen Cicero und Gellius (unpublished habilitation thesis). Tübingen.

Kruger, Michael J. (2013), “Manuscripts, Scribes, and Book Production Within Early Christianity”, in: Stanley E. Porter and Andrew W. Pitts (eds.), Christian Origins and Greco-Roman Culture: Social and Literary Contexts for the New Testament (Text and Editions for New Testament Study 9), Leiden, 15-40.

Larfeld, Wilhelm (1907), Handbuch der griechischen Epigraphik: Bd.1. Einleitungs- und Hilfsdisziplinen. Die nicht-attischen Inschriften. Leipzig.

Laum, Bernhard (1928), Das alexandrinische Akzentuationssystem unter Zugrundelegung der theoretischen Lehren der Grammatiker und mit Heranziehung der praktischen Verwendung in den Papyri (Studien zur Geschichte und Kultur des Altertums 4), Paderborn.

Lefèvre, Eckard (1990), “Die römische Literatur zwischen Mündlichkeit und Schriftlichkeit”, in: Gregor Vogt-Spira (ed.), Strukturen der Mündlichkeit in der römischen Literatur (Script-Oralia 19), Tübingen, 9-15.

Luz, Christine (2010), Technopaignia, Formspiele in der griechischen Dichtung (Mnemosyne. Supplements 324), Leiden/Boston, MA.

Luz, Ulrich (2014), Theologische Hermeneutik des Neuen Testaments, Neukirchen-Vluyn.

Maehler, Margaret (1980), “Der 'wertlose' Aratkodex P. Berol. inv. 5865”, in: Archiv für Papyrusforschung und verwandte Gebiete 1980 (27), 19-32.

Marrou, Henri I. (1956), A History of Education in Antiquity, trans. by George Lamb, London.

Mavrogenes, Nancy A. (1980), "Reading in Ancient Greece”, in: Journal of Reading 8, 691-697.

McNamee, Kathleen (2007), Annotations in Greek and Latin Texts from Egypt (American Studies in Papyrology 45), Oakville, CT.

Metzger, Bruce M. (1962), “The Bodmer Papyrus of Luke and John”, in: The Expository Times 73 (7), 201-203.

Mugridge, Alan. (2016), Copying Early Christian Texts: A Study of Scribal Practice (Wissenschaftliche Untersuchungen zum Neuen Testament 362), Tübingen.

Müller, Peter (1994), “Verstehst du auch, was du liest?"Lesen und Verstehen im Neuen Testament, Darmstadt.

Müller, Rudolf W. (1964), Rhetorische und syntaktische Interpunktion: Untersuchungen zur Pausenbezeichnung im antiken Latein, Tübingen.

Nagy, Gregory (2000), “Reading Greek Poetry Aloud: Evidence from the Bacchylides Papyri”, in: Quaderni urbinati di cultura classica 64 (1), 7-28.

Nässelqvist, Dan (2016), Public Reading in Early Christianity: Lectors, Manuscripts, and Sound in the Oral Delivery of John 14 (Supplements to Novum Testamentum 163), Leiden/Boston, MA.

Nietzsche, Friedrich (1886), Jenseits von Gut und Böse: Vorspiel einer Philosophie der Zukunft, Leipzig.

Norden, Eduard (1898), Die antike Kunstprosa vom VI. Jahrhundert v. Chr. bis in die Zeit der Renaissance, Leipzig.

Oestreich, Bernhard (2012), Performanzkritik der Paulusbriefe (Wissenschaftliche Untersuchungen zum Neuen Testament 296), Tübingen.

Orsini, Pasquale/Clarysse, Willy (2012), "Early New Testament Manuscripts and Their Dates: A Critique of Theological Palaeography", in: Ephemerides theologicae Lovanienses 88, 443-474.

Paap, Anton H. R. E. (1959), Nomina Sacra in the Greek Papyri of the First Five Centuries A.D: The Sources and Some Deductions (Papyrologica Lugduno-Batava 8), Leiden. 
Parkes, Malcolm B. (1993), Pause and Effect: An Introduction to the History of Punctuation in the West, Berkeley.

Pitchford, Nicola. J./ Ledgeway, Tim/Masterson, Jackie (2008), “Effect of Orthographic Processes on Letter Position Encoding" in: Journal of Research in Reading 31 (1), 97-116.

Porter, Stanley E. (2005), “Pericope Markers in Some Early Greek New Testament Manuscripts”, in: Marjo Korpel and Josef M. Oesch (eds.), Layout Markers in Biblical Manuscripts and Ugaritic Tablets (Pericope 5), Assen, 161-176.

Raible, Wolfgang (1991a), Die Semiotik der Textgestalt: Erscheinungsformen und Folgen eines kulturellen Evolutionsprozesses (Abhandlungen der Heidelberger Akademie der Wissenschaften, Philosophisch-Historische Klasse 1991,1), Heidelberg.

Raible, Wolfgang (1991b). Zur Entwicklung von Alphabetschrift-Systemen: Is fecit cui prodest (Sitzungsberichte der Heidelberger Akademie der Wissenschaften, Philosophisch-Historische Klasse 1991,1), Heidelberg.

Rautenberg, Ursula/Schneider, Ute (eds.) (2015), Lesen: Ein Handbuch, Berlin.

Rayner, Keith (1998), “Eye Movements in Reading and Information Processing: 20 Years of Research", in: Psychological Bulletin 124, 372-422.

Rayner, Keith/Pollatsek, Alexander (1996), “Reading Unspaced Text Is Not Easy: Comments on the Implications of Epelboim et al.'s (1994) Study for Models of Eye Movement Control in Reading", in: Vision Research 36 (3), 461-465.

Roberts, C. H. (1970), “Books in the Greco-Roman World and in the New Testament”, in: Peter R. Ackroyd and Christopher F. Evans (eds.), The Cambridge History of the Bible: From the Beginnings to Jerome, Cambridge, 48-66.

Saenger, Paul H. (1982), "Silent Reading: Its Impact on Late Medieval Script and Society”, in: Viator 13, 367-414.

Saenger, Paul H. (1997), Space Between Words: The Origins of Silent Reading (Figurae), Stanford, CA. Sainio, Miia/Hyönä, Jukka/Bingushi, Kazuo/Bertram, Raymond (2007), "The Role of Interword Spacing in Reading Japanese: An Eye Movement Study", in: Vision Research 47 (20), 2575-2584.

Sanders, Henry A. (1935), A Third-Century Papyrus Codex of the Epistles of Paul, Ann Arbor, MI.

Schotter, Elizabeth R./Angele, Bernhard / Rayner, Keith (2012), “Parafoveal Processing in Reading," in: Attention, Perception \& Psychophysics 74 (1), 5-35.

Schubart, Wilhelm (21921), Das Buch bei den Griechen und Römern, Berlin/Leipzig.

Schenkeveld, Dirk M. (1992), “Prose Usages of 'AкоúEıv “To Read”, in: The Classical Quarterly 42 (1), 129-141.

Sedgwick, W. B. (1929), “Reading and Writing in Classical Antiquity”, in: The Contemporary Review $135,90-94$.

Simone, Carlo de (2011), "Ancora sulla Fibula Praenestina (e fine)" in: Simo Örmä and Kaj Sandberg (eds.), Wolfgang Helbig e la scienza dell'antichità del suo tempo: Atti del Convegno Internazionale in Occasione del $170^{\circ}$ Compleanno di Wolfgang Helbig (Acta Instituti Romani Finlandiae 37), Rom, 225-235.

Small, Jocelyn P. (1997), Wax Tablets of the Mind: Cognitive Studies of Memory and Literacy in Classical Antiquity, London/New York, NY.

Starr, Matthew S./Rayner, Keith (2001), "Eye Movements During Reading: Some Current Controversies”, in: Trends in Cognitive Science 5 (4), 156-63.

Svenbro, Jesper (1999), “Archaic and Classical Greece: the Invention of Silent Reading”, in: Guglielmo Cavallo, Roger Chartier and Lydia G. Cochrane (eds.), A History of Reading in the West, Oxford, 37-63.

Svenbro, Jesper (2002), "Stilles Lesen und die Internalisierung der Stimme im alten Griechenland", in: Friedrich Kittler, Thomas Macho and Sigrid Weigel (eds.), Zwischen Rauschen und Offenbarung: Zur Kultur- und Mediengeschichte der Stimme, Berlin, 55-72. 
Svenbro, Jesper (2005), Phrasikleia: Anthropologie des Lesens im alten Griechenland, München. Threatte, Leslie (1980), The Grammar of Attic Inscriptions: Vol. 1 Phonology, Berlin/Boston. Trobisch, David (1996), Die Endredaktion des Neuen Testaments: Eine Untersuchung zur Entstehung der christlichen Bibel (Novum Testamentum et Orbis Antiquus 31), Fribourg et al.

Tuckett, Christopher M. (2003), “'Nomina Sacra': Yes and No?”, in: Jean-Marie Auwers and Henk J. de Jonge (eds.), The Biblical Canons (Bibliotheca ephemeridum theologicarum Lovaniensium 163), Leuven, 431-458.

Turner, E. G. (21987), Greek Manuscripts of the Ancient World (Bulletin Supplement 46), London.

Turner, Eric G. (1968), Greek Papyri: An Introduction, Princeton, NJ.

Usener, Sylvia (1994), Isokrates, Platon und ihr Publikum: Hörer und Leser von Literatur im 4. Jahrhundert v. Chr. (Script-Oralia 63), Tübingen.

Vatri, Alessandro (2012), “The Physiology of Ancient Greek Reading”, in: Classical Quarterly 62 (2), 633-647.

Vegge, Tor (2006), Paulus und das antike Schulwesen: Schule und Bildung des Paulus (Beihefte zur Zeitschrift für die neutestamentliche Wissenschaft und die Kunde der älteren Kirche 134), Berlin/New York, NY.

Vilhauer, Ruvanee P. (2016), “Inner Reading Voices: An Overlooked Form of Inner Speech”, in: Psychosis 8 (1), 37-47.

Vogt-Spira, Gregor (1991), "Vox und Littera: Der Buchstabe zwischen Mündlichkeit und Schriftlichkeit in der grammatischen Tradition", in: Poetica 23, 295-327.

Wallace, Rex (2011), “The Latin Alphabet and Orthography”, in: James Clackson (ed.), A Companion to the Latin Language, Oxford, 7-28.

Wingo, E. O. (1972), Latin Punctuation in the Classical Age (Janua linguarum. Series practica 133), The Hague.

Winskel, Heather/Radach, Ralph/Luksaneeyanawin, Sudaporn (2009), “Eye Movements when Reading Spaced and Unspaced Thai and English: A Comparison of Thai-English Bilinguals and English Monolinguals", in: Journal of Memory and Language 61 (3), 339-351. 